\title{
An Attempt at Conceptualizing the Information City, its Spaces and Their Potentials
}

\author{
Enformasyon Kenti, Mekanları ve Potansiyelleri Üzerine \\ Bir Kavramsallaşttrma Denemesi
}

Senem KAYMAZ KOCA

\section{ABSTRACT}

Throughout history, cities have functioned as centers where information flows, and is used, produced and distributed. However, as a result of transformations in the qualities of information transmitters, cities today are more receptive to anything that comes with the information flow. The information conveyed by the flow transforms the space and the city, and inundates the space with potentials stemming from the essence of the information flow itself. Today, the potentials carried into the space via the information flow diversify, transform, and fill the space, while constantly attributing new meanings to it. In brief, this study, in referring to the emergence of the Information City as the city of today, and assuming it to be full of potentials, brings into question the spaces of this city along with their potentials. The aim of the study is to make conceptual inferences about these new cities, their spaces and their potentials, while creating a discourse set in a new dictionary that can form the basis for an evaluation of these cities.

\section{ÖZET}

Kentler her dönemde enformasyonun aktığı, kullanıldığı, üretildiği ve dağıtıldığı merkezler olarak çalışmış ve bu durumdan etkilenecek mekansal dönüşümleri de beraberinde getirmiştir. Ancak bugün, enformasyon taşıyıcılarının niteliklerinde yaşanan dönüşümlerin etkisiyle, kentler enformasyon akışıla gelen her şeye eskisinden daha açık hale gelmiş, akışla taşınan enformasyon, mekanın ve kentin üretimini, anlamını, kullanımını ve hikayesini dönüştürmüş ve mekan enformasyon akışının özünden gelen potansiyellerle dolmaya başlamıştır. Bu anlamda, günümüzde enformasyon akışı ile mekanın içine taşınan potansiyellerin, mekanı eskisinden daha fazla çeşitlendirmekte, dönüştürmekte, doldurmakta ve mekana yeni anlamlar katmakta olduğu belirtilmelidir. Bu kabuller üzerine ilerleyen bu çalışma, potansiyellerle donatıdığı varsayılan ve 'enformasyon kenti' olarak isimlendirilen bir günümüz kentinin ortaya çıkmaya başladığına işaret ederken, bu kent üzerine kavramsal bir tartışma başlatmaktadır. Çalışmanın amacı ise, bu yeni kent, mekanları ve potansiyelleri üzerine kavramsal çıkarımlarda bulunmaktır. Ayrıca kenti anlamaya dair yeni bir söylem kümesi yaratıp bir sözlük içerisinde toplamaktır. Bu sözlük aracılığılla ise, günümüz kentleri üzerine değerlendirme yapılabilecek bir zemin oluşturmak hedeflenmiştir. 


\section{Introduction}

\section{Problematic}

Spaces and cities have always been the result of the determining dynamics of social transformations throughout history. The transformation experienced today might be accounted for by the mobility that induces the continuous flow of information between countries, cities and spaces. Today the information flow changes and transforms the space and the city, along with their potentials, traditions, references and their program, and new definitions to clarify the space and the city of today are introduced accordingly. Furthermore, it might be stated that information is conveyed from one city or space to another in every period throughout history via the communication tools and the means of transportation of the relevant time depending on their quality. However, while the tools that convey information centuries ago were merely humans, information in our day is conveyed more swiftly, more easily, and in a more diversifying manner with respect to the past owing to the technological qualities of the new communication and transportation tools emerging along with the transition from analogous to digital communication. While information was transmitted from one place to another only through carrier bodies in its early days, bodies do not need to move in the physical space in the new and high-speed world of today to convey information. ${ }^{1}$ In this manner, new information reaches its destination swiftly and finds its location alongside the present information. Similarly, Mark Poster ${ }^{2}$ and Friedrich Kitler ${ }^{3}$ point out that a large amount of information can move on a global scale thanks to the high speed enabled by the developing communication and transportation systems. Today information flows independently from the spaceand time-induced restrictions, while transforming the space and the city.

In this connection, it might be stated that cities function as centers where information flows, and where it is used, produced and distributed in every period of time, and that it brings about spatial transformations. However, it is important to point out that today, as a result of the transformations in the qualities of information transmitters, cities are more receptive to anything that comes through the information flow with respect to the past, that the information conveyed through the flow transforms the production, the meaning, the usage and the story of the space and the city, and that the space is inundated with the

\footnotetext{
1 Bauman, 1998. 2 Poster, 1999.
}

potentials stemming from the essence of the information flow. Today the potentials carried into the space through information flow diversify, transform, and fill the space while attributing new meanings to it more than they did before. In brief, this study points to the fact that a city of today, which is assumed to be full of potentials and that is referred to as the 'Information city', is emerging, while bringing the spaces of this city along with their potentials, into question. Accordingly, this study creates a discourse set on this kind of city, since the main postulation of this study is that the information flow transmits the potentials inherent in the information into this city and that it is thus creating the 'Information City'.

\section{Aims and Methodology}

This study suggests considering the cities of today from a different perspective with a new concept that it raises, the 'Information City'. The aim of this study is to make conceptual inferences on this new city, its spaces and the potentials of these spaces, while creating a discourse set for a better understanding of it, and compile this set in a dictionary. In this manner, this study lays the foundations for the discussions on the cities of today. It should also be noted that the discussion raised here is not developed directly in relation with the architectural product, but by a discourse on the theoretical level.

As illustrated in Table 1, which constitutes the design scheme of the research, this study is composed of two methodologically consecutive phases. The first phase is the part entitled 'A_Acknowledgements', where the postulations of the study are presented. While presenting the four main postulations on which this study is based, this part dwells upon the historical background of the problem, as well. The previously stated postulations may be summarized respectively as follows: A_1 manifests the differences between the concepts of 'information' and 'knowledge'; A_2 selects the spatial potentials to form the basis of the next phase by compiling the discourses available on the transformation of the space and the city; A_3 examines the position of the term 'Information City' put forth in this study among the discourses on the city of today; and lastly A_4 introduces a discourse set on the world orders existing prior to the world organized by information.

In the first part of the second phase, or I_1 of the "IIInferences" section, the potentials presented in A_2 are analyzed. In the second part entitled I_2, the discourse set introduced in A_4 is furthered and en- 
Table 1. Research design: acknowledgments, inferences, epilogue

\section{RESEARCH DESIGN}

\begin{tabular}{|c|c|c|c|c|}
\hline \multicolumn{2}{|r|}{ A_Acknowledgments } & \multicolumn{2}{|r|}{ I_Inferences } & \multirow{3}{*}{$\begin{array}{l}\text { Epilogue } \\
\text { The study ends with a discussion } \\
\text { as to whether the INFORMATION } \\
\text { CITY and its spaces are in a state } \\
\text { of deformation or transformation }\end{array}$} \\
\hline A_1 & $\begin{array}{l}\text { The conceptual relationship } \\
\text { between information and } \\
\text { knowledge }\end{array}$ & \multirow{2}{*}{ I_1 } & \multirow{2}{*}{$\begin{array}{l}\text { The space fueled by its potentials: } \\
\text { The space organized by } \\
\text { information } \\
\text { Inferences on I_1 from A_2 } \\
\text { are presented. }\end{array}$} & \\
\hline A_2 & $\begin{array}{l}\text { Discourses on the transformation } \\
\text { of the space and the city }\end{array}$ & & & \\
\hline A_3 & $\begin{array}{l}\text { Discourses on elucidating the city of } \\
\text { today }\end{array}$ & & $\begin{array}{l}\text { The city born out of its potentials: } \\
\text { INFORMATION CITY }\end{array}$ & \\
\hline A_4 & $\begin{array}{l}\text { On the worlds having existed before } \\
\text { the world organized by } \\
\text { information }\end{array}$ & I_2 & he discourse set introduced & \\
\hline
\end{tabular}

larged within the context of the world order organized by information and thanks to this enlargement, the discourse set of the 'Information City' is created. This new discourse is compiled in the 'Information City' "dictionary".

In the last section of this study following the two abovementioned phases, or the 'Epilogue', whether the 'Information City' and its spaces are a form of deformation or transformation is brought into question.

\section{Acknowledgements}

\section{The Conceptual Relationship Between Information} and Knowledge

Peter Burke ${ }^{4}$ bases the distinction between the concepts of 'information' and 'knowledge' on the difference between 'knowing how' and 'knowing what'. While the concept of information is used to refer to 'what is raw, specific and practical', knowledge refers to what is 'cooked, processed or systematized by thought'. In this context, it might be suggested that information is 'full of potentials', and that it 'carries a large amount of unprocessed data' and becomes knowledge 'provided that it gains meaning or is finalized by passing through the filter of perception'. While information refers to unorganized and disassociated data, knowledge is equipped with meaning; it is historically processed and categorized. In fact, it is impossible to talk about knowledge that is not situated. In brief, knowledge is more disciplined than information. Conversely, information is less value-laden than knowledge. This semantic relation points at the potential of these concepts to transform into one another constantly. Information turns into knowledge, and re- turns to the state of information each time. Furthermore, it may be asserted that the disciplined state of knowledge might disintegrate easier today than it did in the past depending on the qualities of the transmitters and that it may turn back into information. In this respect, information has more potential than before for reformation, transformation, diversification and reference to something else, and it conveys these potentials from space to space and from city to city.

Discourses on the Transformation of the Space and the City

According to Gilles Deleuze and Felix Guattari, two of the philosophers questioning the analytical thinking characteristic of the 20th century, space has come to be defined in terms of heterogeneous conceptions today, rejecting homogenous patterns. This newlyemerging space is a 'smooth space', which is the opposite of 'striated space'. It is immanent, in a moving and fragmented state. Smooth space is based on the concept of 'multiplicity', in which the perception of reality is different. The concept of multiplicity might extend to various directions, intersect with various relations and it is able to define a new space any time. ${ }^{5,6}$

The smooth space of Deleuze based on the idea of multiplicity has similar qualities to the 'Thirdspace', conceptualized by Edward Soja. The first one of the three spaces conceptualized by Soja ${ }^{7}$ is the material, objective and physical space. The second is the 'representation of space'. The third one, the 'space of representation' is the space that encompasses the first and the second spaces, despite being born out of their deconstruction. It is the space of experience, of living. All 
dichotomies, dualities and dialectics are ruptured and reconstructed there. At this point, it is impossible to represent the third space due to the continuous rupture, deformation and fracture it experiences, since nothing in the other space can become so transcendent as to be represented and when it is represented, it loses all of its potential.

Similarly, the 'Heterotopia' conceptualized by Michel Foucault might be considered in the context of transformation of the space. Foucault ${ }^{8}$ establishes heterotopia as the place that does not conform to the norms in utopia considered to be the transtemporal space, which is a transcendent, homogenous and purified space that hosts a perfect society. Heterotopia is a place where time and space are embraced in a different fashion than traditional. The spaces of heterotopia are crowded far beyond the physical condensation created by mobility and population density. Nothing can cling on the heterotopia since it will go beyond being heterotopia when anything adheres to it. It will be a traditional place. Heterotopia enables the entry or the exit of new ideologies, policies, events and actors in a constant manner. For this reason, heterotopia is not homogenous, but heterogeneous. It is the place of multiplicity and mobility. It does not have a solid foundation. Its foundation is slippery and temporary. It does not have a specific form and it may take the form of opposite spaces.

In the context of the transformation of the space and the city, Jean-François Lyotard ${ }^{9}$ refers to a lifespace that transforms slowly from the 'domus' into the modern 'megapolis', which is the network of temporary domiciles. Domus lives a rhythmical story in a domestic time. There is an ideal world story in Domus, where a consistent integrity prevails. Megalopolis, on the other hand, exists in another order of time and space, where the cycle/rhythm is interrupted. A similar narration to Megalopolis might be found in the 'Overexposed City' of Paul Virilio. ${ }^{10}$ The 'Overexposed City' is displayed with a fractal geometry; it is instantaneous, discontinuous and refringent. In this city, aesthetics gave way to instantaneous images and the concept of boundary has changed. The boundaries do not manifest themselves in a chronological and traditional time, but with instantaneous and discontinuous meanings in an instantaneous and discontinuous time.

Similarly, one of the modern philosophers, Nadia Tazi $^{11}$ compares the space to an ever-transforming

\footnotetext{
8 Foucault, 1998. 9 Lyotard, 1998.
}

smooth and fluid globe. This globe resembles a mechanical tabula rasa, or a plate on which nothing is inscribed. Such a space not only formulates omnipresence, thus removing distances or transmitting knowledge, but it also reproduces itself continuously, flows towards any direction/anywhere, leaks and changes their structure. Such a space is named 'cyberspace' by Tazi, while Aldo Bonomi ${ }^{12}$ refers to the space of today as 'the smooth space of hypermodernity', which he conceptualizes with similar qualities.

Likewise, Bauman ${ }^{13}$ states that 'constructed modern spaces' that existed before had solid, permanent and indisputable qualities, yet a third space has emerged following the development of information network on a global scale. According to Mark Poster, ${ }^{14}$ this is the space of today and it should be referred to as an 'information corridor'. This computer-controlled cybernetic space is, according to Virilio, ${ }^{15}$ devoid of dimensions. There is no distinction between here and there.

To sum up, it would be appropriate to consider that the discourses compiled in this part of the study point at the fact that unlike in the past, today space is more loaded with new references, traditions and potentials in the context of transformation of the space and the city. It is also reasonable to classify these potentials, which are thought to be embedded in the abovementioned discourses, under four headings by tracing back the frequently repeated descriptions in these discourses. In other words, it may be asserted that these discourses pointing at transformation also imply that the space is in the process of being loaded with four potentials. These potentials are 'the diversity potential of production of the space', 'polysemy potential of the space', 'transformation potential of the space' and 'compactness potential of the space', since the abovementioned discourses point at the fact that the space is in the process of transformation, while regaining meanings, filling up, and diversifying. Having been extracted out of the relevant discourses and presented in this part of the study, these potentials shall be analyzed in the 'I_1' part of the 'I_Inferences' section.

\section{Discourses on Elucidating the City of Today}

The diversity of the definitions and theories in the modern literature aiming at elucidating the city of today with reference to different theories is remarkable. For instance, John Friedmann ${ }^{16}$ put forth 'the World City' hypothesis, in which he classified cities according

\footnotetext{
11 Tazi, 2000.

12 Bonomi, 2000.

13 Bauman, 1998.
} 
to the international institutions present in them, and at around the same time, Saskia Sassen ${ }^{17}$ brought forward 'the Global City', in which she assessed cities by capital movements. Similarly, Manuel Castells ${ }^{18}$ compiles the cities which become articulated to the global economy and politics and that have a population over 10 million under the title of 'Mega City'. At a later date, Michael Storper ${ }^{19}$ raises the 'Post-Fordist City' theory in which he considered city as the center of economic reflexivity and in terms of production technologies. Joel Garreau, ${ }^{20}$ on the other hand, suggests a new perspective to consider the city of today with the definition of 'Edge City', which is perceived as a single space, offering more job opportunities for the individual to pursue from a bedroom. Later, Edward Soja ${ }^{21}$ suggests six discourses on post-metropolis: 'Flexcity', 'Cosmopolis', 'Expo/is', 'Metropolarities', 'Carceral Archipielagos' and 'Simcities'.

In fact, descriptions of 'Informational City' and 'Information City' that are conceptualized based on the informational relations of the city of today may also be found in the literature. For instance, in his definition of 'Informational City', Manuel Castells ${ }^{22}$ conceptualizes the city as organized around the space of flows, information around interest and power, and the society around networks. In addition, Mark E. Hepworth ${ }^{23}$ defines the 'Information City as cities that are equipped with smart buildings, fiberoptic networks, complex computer networks and other technologies and that have plenty of business districts built for informationrelated activities. On the other hand, Jakka Sairamesh ${ }^{24}$ and Lee Sproull ${ }^{25}$ refer to the 'Information City' in their studies as a city in which business relations, personal ambitions and social activities are carried out within an internet-based cyber structure.

It should be stated at this point that the definition of 'Information City' suggested in this study is different from the definition of 'Information City' in the world literature, yet it is closer to all of the theories presented above to the extent that it may be identified with their references. In this respect, the definition suggested in this study discusses the design, production, usage and the meaning of the space.

\section{On the Worlds Having Existed Before the World Organized by Information}

The information flow between spaces, cities, and countries has created different historical conditions

\footnotetext{
17 Sassen, 1991.

${ }^{20}$ Garreau, 1991.

${ }^{23}$ Hepworth, 1990.

${ }^{18}$ Castells, 1996.

${ }^{21}$ Soja, 2002

${ }^{24}$ Sairamesh, 2004.

${ }^{19}$ Storper, 1997.

${ }^{22}$ Castells, 1999

25 Sproull, 2004.
}

in every period depending on the qualities of the transmitting tools of the relevant time. These different conditions organized the social structure and the economy, along with the understanding of the space and the city, while changing the manner of world perception of the time. In general terms, this study aims at developing a discourse on understanding the world of today, which is acknowledged to be organized by information, primarily through the comparison of qualities of this world with those of the previous worlds. In this connection, three worlds that could not be distinguished from one another with exact dates, but with their respective qualities are brought forward: 'the world organized by land', 'the world organized by mass production' and 'the world organized by information'. What is essential in this respect is the acknowledgement that all of the physical and abstract values produced by a world system changes in status in the other. In this part of the study, an effort is exerted to compile a discourse set on 'the world organized by land' and 'the world organized by mass production', which emerged following the dissolution of the former. This discourse set shall be furthered and expanded in the I_2 part of the 'I_Inferences' section of the study in the context of the world order 'organized by information'.

In the traditional world organized by land, an understanding prevails, according to which the borderlines of life is set, where it is impossible to cross these lines, and in the origin of which lies the sense of community rather than individualism. The members of this community act in unison in the main areas of life with the community upon whom they depend, and they are attached to one another through natural forces, such as customs and kinship. All of the concepts founding this world are considered unalterable by the traditional society, or in a state of transcendence. ${ }^{26}$ The relationship between the communities in the context of information flow is weak, and the communities assume that all of the other communities, spaces, and cities resemble theirs, since they are not aware of one another. The space is dependent upon the natural limits of the human body. It is local and used as an empty area by such a community. Spaces are connected to one another by organic, natural, and compulsory links (Natural Organic Space - Entity). Similarly, the members of the community are connected to the space with innate, organic and compulsory links (Natural Subject). Furthermore, the relationship that the members of the community build with the space is significant. In such a space, using time is also by organic and natural means. Time,

\footnotetext{
${ }^{26}$ Deleuze, 2001.
} 
taken as emptiness, is split into zones. What counts is the natural rhythm (Natural Rhythm - Organic Time). A society that lives in such a rhythm do not worry about representing anything; representation is neither important, nor meaningful (Iconographic Representation).

The Society organized by mass production endeavors to analyze the things that the traditional world has rendered transcendent with land, through human mind and science. As a result of this analysis, the modern world has produced a new level of transcendence, different from that of the traditional world. The characteristics of the concepts in this new level are different from those in the traditional world, and the speed of change is high. As it is in the traditional world, the newly-established perception asserts to be timeless, spaceless and invariable (Transcendence Based On Worldly Means). The spaces of this society resemble mechanical boxes: Members depart from one and enter the other. In such a space, time is split into zones mechanically. The time to be spent in each mechanical box is set and limited: Members are to be at certain places between certain hours (Duration - Mechanical Splitting). Mechanical spaces are empty on the inside; they are homogenous and they have permanent and representable qualities in terms of transcendence. They are free from the natural limitations of the human body. They do not like transformation and they are in search of the ideal form (Artificially Constructed Cartesian Space - Result). The subject utilizing this space is a completely self-controlling subject, who experiences the time-space conforming to the rules (Mechanical / Normative Subject). This society considers that everything necessarily has a background story. It is common to imagine creating a tool to represent the whole and complete knowledge by means of reason. (Compulsory Representation). The opportunities for encountering and being informed about one another through information flow are plenty in such a world.

\section{Inferences}

\section{The Space Fueled by Its Potentials:}

The Space Organized by Information

In this part of the study, which focuses upon the problematic asserting that information is full of potentials, transmits these potentials to spaces and cities, and changes the structure of both the space and the city, inferences will be presented on four potentials, which were conceptualized in the 'Acknowledgements' section above. In other words, the effect of the potentials extracted out of the discourses on the transformation of the space and the city compiled in A_2 are presented in this part of the study. These potentials assumed to have been loaded in the space are considered to be a means for understanding the city of today, designated as the 'Information City'.

\section{Diversity Potential of the Production of the Space}

This potential highlights the diversity of the spatial production activities in the city. In a world, where information flows as smoothly as it does today, it may be stated that the production activities, the stories on space, the designs and the forms are also being transmitted, and that the spatial production activities are getting diversified and hybridized as a result. Furthermore, this condition also reveals the potential of unveiling different thoughts and creating spaces of different types, since what it disseminates and hybridizes is the spaces created with pluralistic and nonlinear thought that are not based on cause and effect relationship and the cities that might be defined with such concepts as complexity, chaos, and fractal dimensions. In brief, the diversity potential of spatial production does not work in a hierarchical structure that operates with old principles; it rejects transcendences, since spatial production is loaded with absolutisms via transcendences. Yet the diversity potential of the production activities of the spaces of today neither limits, nor forces spatial production. It releases the probabilities, and encourages movement and change. This potential does not refer to the ideal association or smoothness of the parts within production activity, but to their diversity, and diversity tends to remove borderlines, representations and patterns.

\section{Polysemy Potential of the Space}

Today, the space is open for more meanings than ever before, thanks to the information flow. By absorbing the information brought along with this flow, the space has increased its potential to be loaded with meaning. Bearing opposite meanings lies beneath this new potential of polysemy that the space has adopted. This is due to the fact that the flow also transmits opposite information into the space. In this respect, antonymous structures like local-global, virtual-real, singular-universal, and physical-nonphysical may coexist in the space. Furthermore, this new potential of polysemy of the space vanishes when it is represented. In other words, the space adopts a new structure that can no longer be represented with a story, an identity or a value. Moreover, the space is cleaned out of productions made through necessary concepts and stereotyped thoughts of the past. None of the spatial 
productions have a necessary story in its background. Therefore, the space organized by information does not imply anything but itself, nor does it have a visual or symbolically iconographic nature.

\section{Transformation Potential of the Space}

As it is stated in the Acknowledgements section of the study, prior to the world organized by information, spaces used to be designed by taking the fact that they had specific functions into consideration and that they had fixed functions and forms. Yet today, the spaces of information have become different from common types of usage. They have become flexible and acquired the potential of transformation. These spaces may no longer be designed based on their specific purposes and their usages are interwoven. This means that there is no longer a clear-cut distinction between spaces and that the necessary movement between spaces has changed. Furthermore, space of information cannot have a fixed form or limits. In brief, spaces of information, which are the opposite of the spaces with objective, physical and representable transcendent qualities, are flexible and immanent spaces that do not have concerns about possessing the ideal form. It is impossible to consider the spaces of information in a complete state.

\section{Compactness Potential of the Space}

The space organized by information has a more occupied structure vis-à-vis the previous spaces. Beyond physical compactness, the information space is full of volume resulting from the information flow. In other words, the incoming information by means of the flow results in the compactness of these spaces, and it compresses them. This space thus has liveliness; it is fresh with life, since everything accumulates in the information space, occupies a place in its memory and accordingly fills this space. Owing to this compactness potential, a large amount of humans, identities, multitude, relations and thoughts pass through continuously. Hence, the space has acquired a structure, which is open to be fed with information, to thrive, to proliferate, and to be diversified. It is flexible and fluid.

\section{The City Born out of its Potentials: \\ 'Information City'}

In this part of the study, efforts have been exerted to compile a dictionary on understanding today's world that is acknowledged to be organized by information and to present these efforts by developing the discourse on understanding previous worlds that is dwelt upon in part A_4. For this reason, the dictionary presented in Table $2 a, 2 b, 2 c$ and $2 d$ at the end of this part contains not only the discourse of the world organized by information, but also that of the previous worlds in order to enable comparison.

The city organized by information, or the 'Information City' as it is designated in this study, is the city of the society of today that may be referred to as the multitude. The multitude that lives in this city is composed of individuals that cannot simply be considered under the same title and of specialized social relations. The multitude comprehends this world in a different manner than before. For instance, the assertion of the world organized by mass production to be timeless, spaceless and invariable begins to dissolve in this new world and leaves its place to the idea that objects do not occupy invariable positions in the world. In this sense, the ontologies and authorities that are thought to be strong start to fall. What lies beneath the manner of comprehending this world for the multitude is immanence. ${ }^{27}$ In other words, the idea that nothing necessarily has a background story is common. Therefore, a dissolution in the logic of representation has been experienced.

'Information City' encloses the potentials transmitted through information flow and gives the spaces that it contains their respective shapes. The space organized by information having arisen accordingly does not conform to the norms of the past. This space is flexible, smooth and fluid. It likes transformation and it does not have a concern about searching for the ideal form. Its boundaries are neither chronological, nor traditional. It is identified with fractal geometry and does not imply anything but itself. Moreover, this space is lively, heterogeneous, impermanent and fragmental. Having been conceptualized as a Slippery/ Smooth Space in this study, this space is in a constant state of becoming. ${ }^{28}$ This state supplies the space with the potentials of constant diversification, expression of another thing, transformation, and emptying and refilling up, since the space organized by information fills up with information transmitted through the constant flow and the potentials embedded in this information. It is also possible to define the 'Information City' as a city that accumulates these incoming potentials resulting from the flow and that can use what is accumulated.

This new space that is loaded with potentials might become different as a result of bending, loosening and folding. In this case, evaluation and representation of the space is rendered more difficult. In this connec-

\footnotetext{
${ }^{27}$ Deleuze, 2001.
} 
Table 2a. INFORMATION CITY DICTIONARY_ Distinctions

INFORMATION CITY DICTIONARY_Distinctions

\begin{tabular}{|c|c|c|c|}
\hline \multicolumn{4}{|c|}{ INFORMATION CITY DICTIONARY__Distinctions } \\
\hline 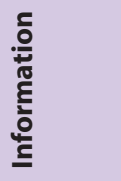 & \multicolumn{3}{|c|}{$\begin{array}{l}\text { Information is full of potentials. It carries a large amount of unprocessed and disassociated data and becomes knowledge } \\
\text { provided that it gains meaning or is finalized by passing through the filter of perception. It has a constant potential of } \\
\text { transformation into one another with knowledge. }\end{array}$} \\
\hline 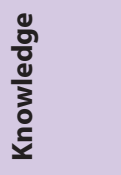 & \multicolumn{3}{|c|}{$\begin{array}{l}\text { Knowledge is equipped with meaning; it is historically processed and categorized. It is a more disciplined, structured, and } \\
\text { positioned version of information. }\end{array}$} \\
\hline 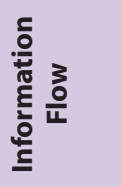 & \multicolumn{3}{|c|}{$\begin{array}{l}\text { Transmitted by the communication tools and the means of transportation of today, information does not flow between } \\
\text { spaces, cities and countries over a linear path, but in a random manner. The flow is exposed to any accidents and } \\
\text { coincidence. }\end{array}$} \\
\hline 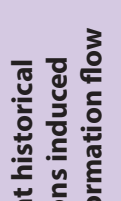 & \multicolumn{3}{|c|}{$\begin{array}{l}\text { The information flow has created different historical conditions in every period depending on the qualities of the } \\
\text { transmitting tools of the relevant time. These different conditions organized the social structure and the economy, } \\
\text { along with the understanding of the space and the city. In this connection, three worlds that could not be distinguished } \\
\text { from one another with exact dates, but with their respective qualities are brought forward: }\end{array}$} \\
\hline 青 & $\begin{array}{l}\text { WORLD ORGANIZED } \\
\text { BY LAND }\end{array}$ & $\begin{array}{c}\text { WORLD ORGANIZED } \\
\text { BY MASS } \\
\text { PRODUCTION } \\
\end{array}$ & $\begin{array}{l}\text { WORLD ORGANIZED } \\
\text { BY INFORMATION }\end{array}$ \\
\hline 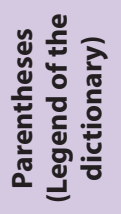 & $\begin{array}{l}\text { Throughout this dictionary, the content } \\
\text { marked with this colour refers to the } \\
\text { discourse of the WORLD ORGANIZED } \\
\text { BY LAND. }\end{array}$ & $\begin{array}{l}\text { Throughout this dictionary, the content } \\
\text { marked with this colour refers to the } \\
\text { discourse of the WORLD ORGANIZED BY } \\
\text { MASS PRODUCTION. }\end{array}$ & $\begin{array}{l}\text { Throughout this dictionary, the content } \\
\text { that is not marked by any colour refers } \\
\text { to the discourse of the WORLD } \\
\text { ORGANIZED BY INFORMATION. }\end{array}$ \\
\hline 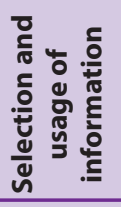 & $\begin{array}{l}\text { No discussion on good knowledge or } \\
\text { bad knowledge. }\end{array}$ & $\begin{array}{l}\text { Good knowledge is distinguished from } \\
\text { bad knowledge and correct knowledge } \\
\text { from incorrect knowledge. }\end{array}$ & $\begin{array}{l}\text { The production and dissemination of } \\
\text { information precede its selection in } \\
\text { importance. }\end{array}$ \\
\hline 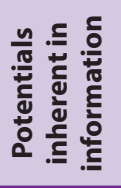 & \multicolumn{3}{|c|}{$\begin{array}{l}\text { Information has the potentials of constant reformation, movement and reference to something else. It is open to new } \\
\text { formations, new productions and other meanings and transformation. It has diversity, polysemy, transformation and } \\
\text { compactness in its nature. It includes opposite/contradictory meanings. }\end{array}$} \\
\hline 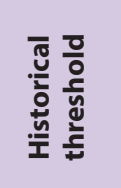 & \multicolumn{3}{|c|}{$\begin{array}{l}\text { The historical threshold roughly corresponding to early } 1980 \text { s points at the change in the qualities of the communication } \\
\text { tools and the means of transportation following the transition from analog to digital communication. With this change, } \\
\text { the transportation of information has been accelerated, developed mobility in larger amounts, and its production has } \\
\text { been diversified. The probability of its transformation during the flow has increased, as well. }\end{array}$} \\
\hline \multirow{2}{*}{ 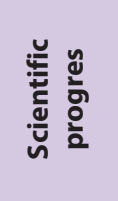 } & $\begin{array}{l}\text { Effort for setting up a hierarchical order } \\
\text { of nature according to scholastic logic. }\end{array}$ & $\begin{array}{l}\text { Effort for setting up a cause-and-effect } \\
\text { relationship }\end{array}$ & $\begin{array}{l}\text { Thought that nothing is simple and } \\
\text { linear as in Newtonian paradigm. }\end{array}$ \\
\hline & $\begin{array}{l}\text { ARISTOTELIAN } \\
\text { PHYSICS }\end{array}$ & $\begin{array}{l}\text { NEWTONIAN } \\
\text { PHYSICS }\end{array}$ & $\begin{array}{l}\text { EINSTEINIAN } \\
\text { PHYSICS }\end{array}$ \\
\hline
\end{tabular}


Table 2b. INFORMATION CITY DICTIONARY_Conceptuality

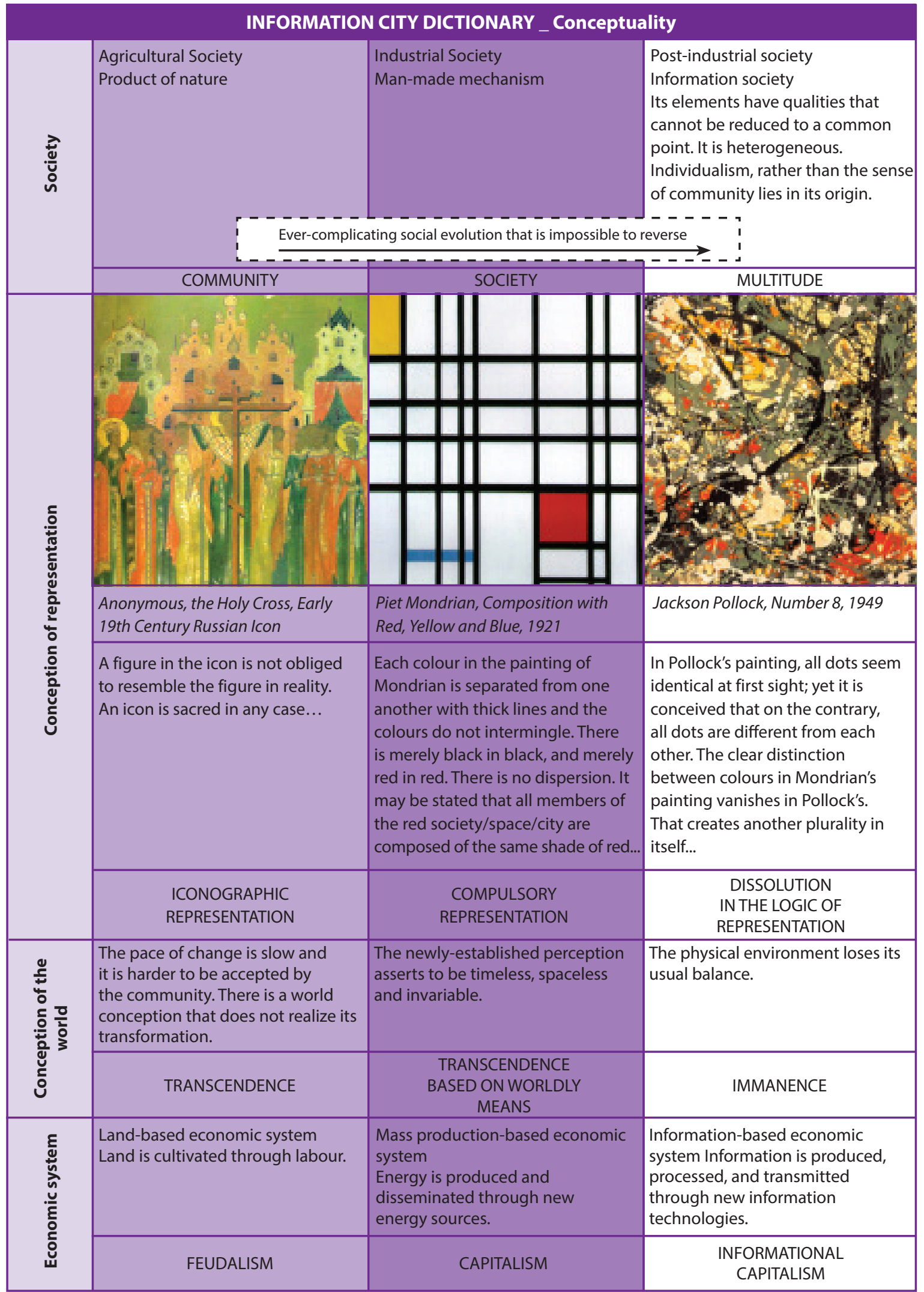


Table 2c. INFORMATION CITY DICTIONARY_Temporal and Spatial Cognition

\begin{tabular}{|c|c|c|c|}
\hline \multicolumn{4}{|c|}{ INFORMATION CITY DICTIONARY_Temporal and Spatial Cognition } \\
\hline \multirow{4}{*}{$\begin{array}{l}\text { đँ } \\
\text { in }\end{array}$} & \multicolumn{3}{|c|}{$\begin{array}{l}\text { The information space in this dictionary is defined as S L I P P E RY / S M O O T H S P A C E. The other } \\
\text { names of this space mentioned in the literature: Thirdspace, heterogeneous space, fractal space, anti-utopia, } \\
\text { the space of flows... }\end{array}$} \\
\hline & Objective and physical space & $\begin{array}{l}\text { Rational space that has representable } \\
\text { transcendental qualities: Mechanical } \\
\text { empty boxes }\end{array}$ & $\begin{array}{l}\text { Space that does not conform to the } \\
\text { norms: Intertwined usage... }\end{array}$ \\
\hline & $\begin{array}{l}\text { house } \\
\text { workplace } \\
\text { school } \\
\quad \ldots\end{array}$ & $\begin{array}{c}\text { pleasure } \\
\text { ground }\end{array}$ & \\
\hline & $\begin{array}{l}\text { ENTITY } \\
\qquad \\
\text { NATURAL ORGANIC } \\
\text { SPACE }\end{array}$ & $\begin{array}{l}\text { RESULT } \\
\cdot \\
\text { ARTIFICIALLY } \\
\text { CONSTRUCTED } \\
\text { CARTESIAN SPACE }\end{array}$ & $\begin{array}{l}\text { BECOMING } \\
\text { SLIPPERY / SMOOTH } \\
\text { SPACE }\end{array}$ \\
\hline \multirow{4}{*}{ 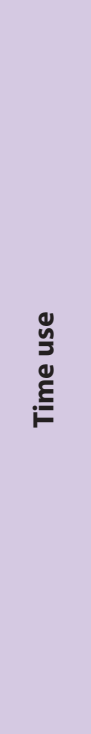 } & $\begin{array}{l}\text { The day starts with sunrise and ends at } \\
\text { sunset: Sunrise/Sunset }\end{array}$ & $\begin{array}{l}\text { City of the hour: Work starts at } 09: 00 \text { in } \\
\text { the morning and ends at 18:00 in the } \\
\text { evening. It may be dark or light when } \\
\text { work starts or ends. }\end{array}$ & $\begin{array}{l}24 \text { hours are distributed unevenly in } \\
\text { these spaces. }\end{array}$ \\
\hline & & 2 hours & \\
\hline & & 10 hours $\longleftrightarrow 8$ hours & \\
\hline & $\begin{array}{l}\text { NATURAL RHYTHM } \\
\cdot \cdot \\
\text { ORGANICTIME }\end{array}$ & $\begin{array}{l}\text { DURATION } \\
\text { MECHANICAL } \\
\text { SPLITTING }\end{array}$ & $\begin{array}{c}\text { PROCESS } \\
\cdot \dot{ } \\
\text { FUZZY SPLITTING }\end{array}$ \\
\hline \multirow{3}{*}{ 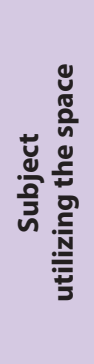 } & \multicolumn{3}{|c|}{$\begin{array}{l}\text { The subject utilizing INFORMATION CITY is N OMADIC SUBJECT. This subject experiences the spaces with } \\
\text { his/her free will without any supervision or regulation. He/she is on the move even when it is standing still } \\
\text { in the slippery space. }\end{array}$} \\
\hline & $\begin{array}{l}\text { Subject utilizing the nature while utili- } \\
\text { zing the space }\end{array}$ & $\begin{array}{l}\text { Subject experiencing the time-space } \\
\text { according to the norms }\end{array}$ & $\begin{array}{l}\text { Subject involuntarily participating in } \\
\text { spatial orientations }\end{array}$ \\
\hline & NATURAL SUBJECT & $\begin{array}{l}\text { MECHANICAL } \\
\text { NORMATIVE } \\
\text { SUBJECT }\end{array}$ & NOMADIC SUBJECT \\
\hline
\end{tabular}


Table 2d. INFORMATION CITY DICTIONARY_Potentials/Inferences

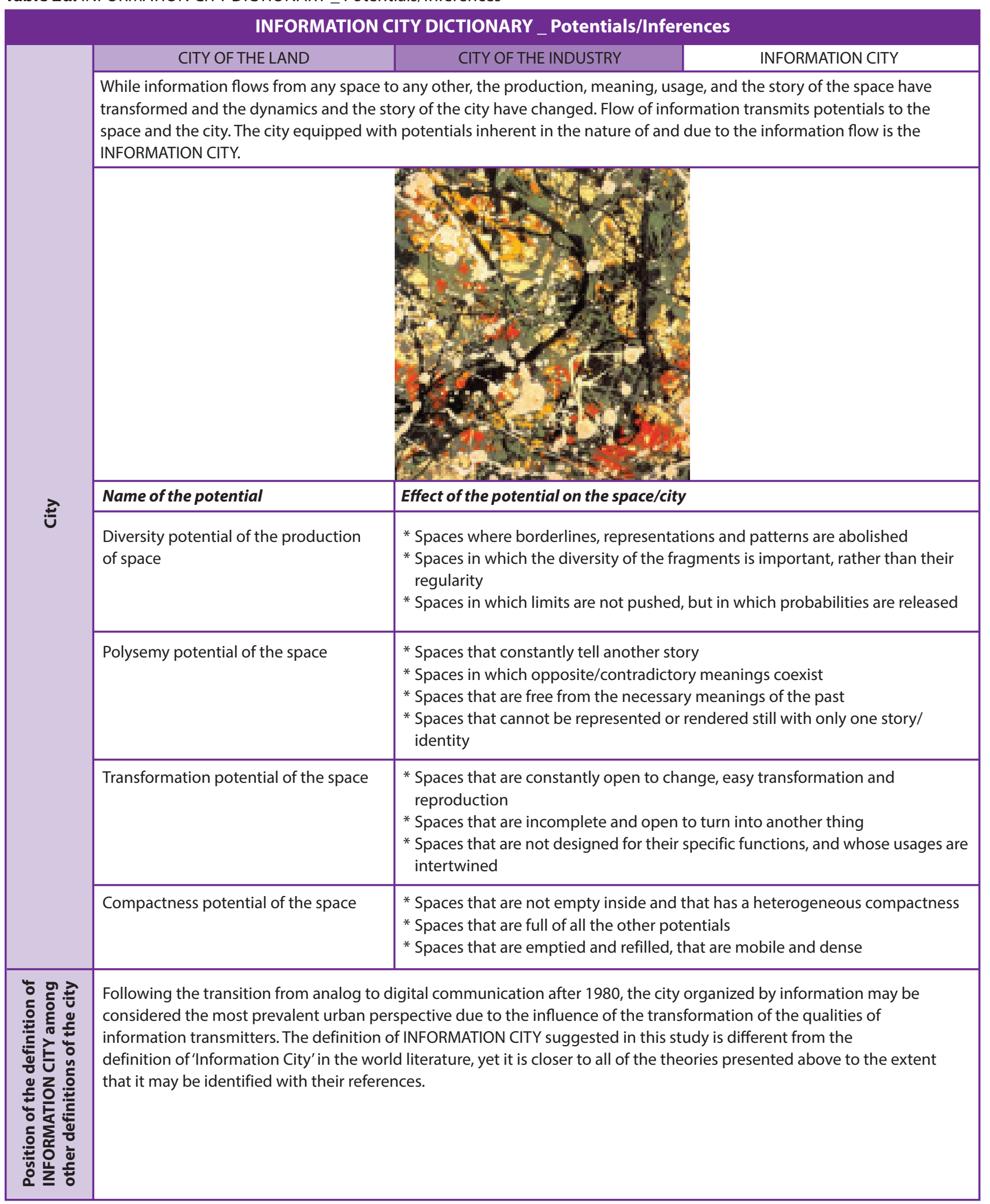


tion, the usages of the spaces organized by information are intertwined. 24 hours are distributed unevenly in these spaces. The number of hours to spend in a given space is not fixed, but flexible. Therefore the time spent in the space is conceptualized as fuzzy splitting.

The subject of such a space is conceptualized as a nomadic subject, ${ }^{29}$ whose qualities are exactly the opposite of those of the normative subject. This subject experiences the spaces with his/her free will without any supervision or regulation.

\section{Epilogue: Deformation Or Transformation?}

This study ends in this part with a discussion as to whether the 'Information City', which is composed of the spaces organized by information is in a state of deformation or transformation. The reason that necessitates ending the study with such a discussion is that the information transmitted through the flow loads the information spaces and cities with the potentials of diversity, polysemy, openness to transformation, and compactness that are embedded in this information, and that 'Information City' is defined with a constant mobility for this very reason. In other words, the potentials carried by means of the information flow is altering the space and the city, and the need for clarifying whether this alteration is to be defined as a 'deformation', or as a 'transformation' arises accordingly. There is no doubt that 'deformation' implies a negative state, while 'transformation' implies a 'usual' condition. To demonstrate this case with an example, it might be stated that the new information created in the city may be interpreted in two ways. On one hand, it may be interpreted as 'the disappearance of the previous information and the creation of another in its place', which is a change of state referred to as a 'deformation'. On the other hand, it may also be interpreted as 'the replacement of the previous information with a new one at the end of a usual transition process'. This latter change of state implies a transformation.

In this respect, it might be stated that the information flow entails a transformation in the city and its spaces, rather than a deformation, since every new situation created by the information flow is affected and fed by the conditions of the previous situation, and it evolves accordingly. Such an evolution may be clarified with 'transformation', which implies the 'natural one', rather than 'deformation', which implies 'abandoning the old one'. Therefore, this city experiences a con-

\footnotetext{
${ }^{29}$ Lorraine, 2005.
}

stant transformation as a result of usual situations. In this context, it may also be stated that the city in the process of transformation is also in a state of incompleteness. Yet, this state does not entail any negativity, since it points at the fact that 'Information City' is a constantly changing and easily transforming city.

Being an attempt at conceptualizing the 'Information City', this study has made efforts to see the layers beyond the visible, to produce new ideas on how it would be in other cases, and to consider the space as becoming.

\section{References}

1. Arsic, B. (2005) "Thinking Leaving", Ed.: I. Buchanan and G. Lambert (editors) Deleuze and Space, Edinburg, Edinburg University Press, pp. 126-143.

2. Bauman, Z. (1998) Globalization: The Human Consequences, New York, Colombia University Press.

3. Bonomi, A. (2000) "Smooth Space", Ed.: R. Koolhaas (editor) Mutations, Barcelona, Actar Publishing, pp. 450-457.

4. Burke, P. (2000) A Social History of Knowledge, Cambridge, Polity Press-Blackwell Publishers.

5. Castells, M. (1996) The Information Age: Economy, Society and Culture, The Rise of the Network Society, Vol. I, Oxford, Blackwell.

6. Castells, M. (1999) The Informational City, Information Technology, Economic Restructuring, and the Urban-Regional Process, Oxford, Blackwell.

7. Deleuze, G. (2001) Pure Immanence: Essays on a Life, Trans: Anne Boyman (Translator), New York, Zone Books.

8. Dewsbury, J.D. and Thrift, N. (2005) "“Genesis Eternal": After Paul Klee", Ed.: I. Buchanan and G. Lambert (editors) Deleuze and Space, Edinburg, Edinburg University Press, pp. 89-108.

9. Foucault, M. (1998) "Of Other Spaces: Utopias and Heterotopias", Ed.: N. Leach (editor) Rethinking Architecture, London, Routledge, pp. 350-356.

10. Friedmann, J. (1986) "The World City Hypothesis", Development \& Change, Vol. 17, pp. 69-83.

11. Garreau, J. (1991) Edge City: Life on the New Frontier, New York, Doubleday.

12. Hepworth, M.E. (1990) "Planning for the Information City: The Challenge and Response", Urban Studies, No. 4, Vol. 27, pp. 527-558.

13. Kitler, F. (2000) “What's New about the New Media”, Ed.: R. Koolhaas (editor) Mutations, Barcelona, Actar Publishing, pp. 58-69.

14. Lorraine, T (2005) "Ahad and Becoming-Whale: The Nomadic Subject in Smooth Space", Ed.: I. Buchanan and G. Lambert (editors) Deleuze and Space, Edinburg, Edinburg University Press, pp. 159-175.

15. Lyotard, J.-F. (1998) "Domus and The Megalopolis", Ed.: N. Leach (editor) Rethinking Architecture, London, Routledge, pp. 271-279.

16. Poster, M. (1996) "Database as Discourse, or Electronic Interpellations", Ed.: P. Heelas, S. Lash and P. Morris 
(editors) Detraditionalization, Oxford, Blackwell, pp. 277293.

17. Poster, M. (1999) "National Identities and Communications Technologies", The Information Society, Vol. 15, pp. 235-240.

18. Sairamesh, J., Lee, A. and Anania, L. (2004) "Information Cities", Communications of the ACM, No. 2, Vol. 47, pp. 29-31.

19. Sassen, S. (1991) The Global City, Princeton, Princeton University Press.

20. Soja, E. (1996) Thirdspace, Journeys to Los Angeles and Other Real-and-Imagined Places, Oxford, Blackwell.

21. Soja, E. (2002) "Postmetropolis Üzerine Alt Söylem”, Ed.: B. Duru and A. Alkan (editor) 20. Yüzyıl Kenti, Ankara, İmge Publishing, pp. 285-306.

22. Sproull, L. and Patterson, J.F. (2004) "Making Information Cities Livable", Communications of the ACM, No. 2, Vol. 47, pp. 33-37.
23. Storper, M. (1997) "The City: Centre of Economic Reflexity", The Service Industrial Journal, No. 1, Vol. 17, pp. 1-27.

24. Tazi, N. (2000) "Fragments of Net-Theory", Ed.: R. Koolhaas (editor) Mutations, Barcelona, Actar Publishing, pp. 42-50.

25. Virilio, P. (1991) The Lost Dimension, New York, Semiotext(e).

26. Virilio, P. (1998) "The Overexposed City", Ed.: N. Leach (editor) Rethinking Architecture, London, Routledge, pp. 381-390.

Key words: Compactness; diversity; information city; polysemy; spatial potentials; transformation.

Anahtar sözcükler: Doluluk; çeşitlilik; enformasyon kenti; çok anlamIılı; mekansal potansiyeller; dönüşüm. 